\title{
PELATIHAN PENANGANAN DAN PENGOLAHAN SUSU KAMBING DI NAGARI BUKIT BATABUH KABUPATEN AGAM
}

\section{Sahadi Didi Ismanto*, Hasbullah, Anwar Kasim, Fauzan Azima, Kesuma Sayuti, Rini, Novizar, Neswati, Tuty Anggraini, Netty Sri Indeswari}

Jurusan Teknologi Hasil Pertanian Fakultas Teknologi Pertanian Universitas Andalas

Corespondensi Author: sahadididiismanto@gmail.com

\begin{abstract}
ABSTRAK
Permasalahan utama yang dihadapi kelompok saat ini adalah terbatasnya pengetahuan, teknologi dan peralatan produksi untuk mengolah susu kambing. Susu yang dihasilkan hanya diolah menjadi susu pasteurisasi di dalam kemasan kantong plastik. Dalam hal penanganan susu segar, penerapan kebersihan, praktik higiene, dan sanitasi juga masih belum baik. Dengan demikian, susu segar dan susu pasteurisasi yang mereka produksi dan pasarkan belum dapat dijamin keamanannya untuk dikonsumsi. Di samping keterbatasan penguasaan teknologi juga belum optimalnya kelembagaan kelompok yang baru berjalan sebatas bekerja sama dalam hal teknis berternak, namun belum berkembang dalam hal pengadaan bersama dan pemasaran produk secara bersama. Dengan demikian tingkat efisiensi dalam hal biaya produksi dan biaya pemasaran belum bisa diperoleh oleh kelompok. Masalah sebagaimana yang dijelaskan di atas, ditawarkan untuk diselesaikan dengan alternatif sebagai berikut a) Memberikan pelatihan teknik kebersihan, sanitasi dan higienis pemerahan dan penanganan susu segar dan susu pasteurisasi, serta teknik pengemasan; b) Memberikan pelatihan teknik pengolahan susu menjadi berbagai produk olahan susu c) Memberikan Peningkatan wawasan dan pengetahuan kelompok mengenai pemasaran produk olahan susu kambing d) Memberikan pelatihan penguatan kelembagaan kelompok peternak kambing untuk menuju kelompok tani yang profesional.
\end{abstract}

Kata Kunci : Susu Kambing, Ternak Kambing, Olahan Susu Kambing, Kambing Etawa

\section{PENDAHULUAN}

\section{Analisis Situasi}

Nagari Bukik Batabuah adalah salah satu dari 82 nagari yang ada di Kabupaten Agam dan sekarang termasuk dalam wilayah Kecamatan Canduang. Nagari Bukik Batabuah terletak pada $100^{\circ} 30^{\prime}-100^{\circ} 31^{\prime}$ BT dan $0^{\mathrm{O}} 25^{\prime}-0^{\mathrm{O}} 27^{\prime} \mathrm{LS}$.

Pusat pemerintahan Nagari Bukit Batabuah adalah Kubu Apa Jorong Batabuah Koto Baru. Nagari Bukik Batabuah terdiri dari 4 Jorong dan 16 Kampung. Keempat jorong tersebut yaitu, Jorong Batang
Silasiah, Gobah, Kubang Duo Koto Panjang dan Batabuah Koto Baru. Nagari Bukik Batabuah mempunyai luas wilayah lebih kurang 1.122 ha $\left(11,22 \mathrm{~km}^{2}\right)$.

Salah satu sektor unggulan di nagari ini adalah peternakan Kambing Etawa untuk diperah susunya oleh Kelompok Peternak Rantiang Ameh. Susu kambing yang dihasilkan dijual sebagai susu segar dan susu pasteurisasi dengan harga $\mathrm{Rp} 30.000,00$ per liter. Susu yang tidak segera terjual disimpan di dalam lemari pendingin. Kadang- kadang susu harus dibekukan 
karena tidak terjual lebih dari dua hari.

Selain dikonsumsi langsung, seperti susu sapi, susu kambing dapat diolah menjadi berbagai produk seperti yoghurt dan kefir (dengan fermentasi), krim dan mentega (dengan proses creaming), keju (dengan proses koagulasi kasein), dan permen susu (dengan pemanasan bersama gula).

Sampai saat ini, susu kambing yang dihasilkan oleh Kelompok Peternak Ranting Ameh belum ada yang diolah selain dipasteurisasi. Proses pasteurisasi ini tidak menghasilkan nilai tambah karena harga jual susu segar dan susu pasteurisasi adalah sama.

\section{Permasalahan Mitra}

Permasalahan utama yang dihadapi kelompok saat ini adalah terbatasnya pengetahuan, teknologi dan peralatan produksi untuk mengolah susu kambing. Itulah yang di antaranya yang menyebabkan sampai sekarang, susu yang dihasilkan hanya diolah menjadi susu pasteurisasi di dalam kemasan kantong plastik.

Dalam hal penanganan susu segar, penerapan kebersihan, praktik higiene, dan sanitasi juga masih belum baik. Dengan demikian, susu segar dan susu pasteurisasi yang mereka produksi dan pasarkan belum dapat dijamin keamanannya untuk dikonsumsi.

Di samping keterbatasan penguasaan teknologi juga belum optimalnya kelembagaan kelompok yang baru berjalan sebatas bekerja sama dalam hal teknis bertani, namun belum berkembang dalam hal pengadaan bersama dan pemasaran produk secara bersama. Dengan demikian tingkat efisiensi dalam hal biaya produksi dan biaya pemasaran belum bisa diperoleh oleh kelompok.

\section{TARGET DAN LUARAN}

\section{Solusi yang ditawarkan}

Masalah sebagaimana yang

dijelaskan di atas, ditawarkan untuk

diselesaikan dengan alternatif

sebagai berikut :

1) Memberikan pelatihan cara penanganan susu segar dan susu pasteurisasi yang bersih, higienis dan menerapkan praktik sanitasi yang baik.

2) Memberikan pelatihan cara pengolahan susu kambing menjadi berbagai produk olahan seperti pembuatan kompos dengan memanfaatkan kotoran sapi dan kotoran ayam broiler, sisa hijauan makanan ternak dan limbah pertanian yang dihasilkan.

3) Memberikan pelatihan penguatan kelembagaan kelompok peternak untuk menuju kelompok yang lebih profesional.

\section{Target Luaran}

Sesuai dengan rencana kegiatan maka dapat dijelaskan target keluaran seperti Tabel 1 berikut ini:

Tabel 1. Target Keluaran dari Kegiatan yang Akan dilaksanakan 


\begin{tabular}{|c|c|c|c|c|}
\hline No & $\begin{array}{c}\text { Permasalahan } \\
\text { Mitra }\end{array}$ & Solusi & Kegiatan & Keluaran \\
\hline 1. & $\begin{array}{l}\text { Belum } \\
\text { mampu } \\
\text { memproduksi } \\
\text { susu segar } \\
\text { dan susu } \\
\text { pasteurisasi } \\
\text { yang higienis } \\
\text { yang dikemas } \\
\text { dengan } \\
\text { kemasan } \\
\text { yang menarik }\end{array}$ & $\begin{array}{l}\text { Peningkatan } \\
\text { pengetahuan dan } \\
\text { teknik kebersihan, } \\
\text { sanitasi dan higienis } \\
\text { pemerahan dan } \\
\text { penanganan susu } \\
\text { segar dan susu } \\
\text { pasteurisasi, serta } \\
\text { teknik pengemasan }\end{array}$ & $\begin{array}{l}\text { Metode } \\
\text { pelatihan, } \\
\text { bimbingan } \\
\text { dan } \\
\text { konsultasi }\end{array}$ & $\begin{array}{l}\text { 1. } 80 \% \text { anggota kelompok } \\
\text { mengerti mengenai penting } \\
\text { kebersihan, sanitasi dan } \\
\text { higienis pada penanganan } \\
\text { susu segar dan pasteurisasi } \\
\text { 2. Penanganan susu segar dan } \\
\text { susu pasteurisasi dilakukan } \\
\text { dengan cara yang lebih } \\
\text { bersih, lebih higienis dan } \\
\text { lebih menerapkan praktik } \\
\text { sanitasi }\end{array}$ \\
\hline 2. & \begin{tabular}{|l|} 
Belum \\
mampu \\
mengolah \\
susu kambing \\
menjadi \\
berbagai \\
produk olahan \\
susu
\end{tabular} & $\begin{array}{l}\text { Pemberian } \\
\text { pengetahuan dan } \\
\text { teknik pengolahan } \\
\text { susu menjadi } \\
\text { berbagai produk } \\
\text { olahan susu }\end{array}$ & $\begin{array}{l}\text { Metode } \\
\text { pelatihan, } \\
\text { bimbingan } \\
\text { dan } \\
\text { konsultasi }\end{array}$ & $\begin{array}{l}\text { Semua anggota kelompok mampu } \\
\text { mengolah susu segar menjadi } \\
\text { salah satu produk olahan susu }\end{array}$ \\
\hline 3 & $\begin{array}{l}\text { Belum } \\
\text { mengetahui } \\
\text { peluang } \\
\text { pemasaran } \\
\text { produk } \\
\text { olahan susu } \\
\end{array}$ & $\begin{array}{l}\text { Peningkatan } \\
\text { wawasan dan } \\
\text { pengetahuan } \\
\text { kelompok mengenai } \\
\text { pemasaran produk } \\
\text { olahan susu kambing }\end{array}$ & $\begin{array}{l}\text { Penjelasan } \\
\text { dan Praktek }\end{array}$ & $\begin{array}{l}\text { Semua anggota kelompok } \\
\text { mengetahui peluang pemasaran } \\
\text { produk olahan susu. }\end{array}$ \\
\hline 4 & $\begin{array}{l}\text { Belum kuatnya } \\
\text { kelembagaan } \\
\text { yang ada }\end{array}$ & $\begin{array}{l}\text { Perlu peningkatan } \\
\text { kemampuan } \\
\text { pengelolaan } \\
\text { kelembagaan, } \\
\text { menyusun laporan } \\
\text { keuangan sederhana } \\
\text { yaitu penyusunan:1) } \\
\text { Buku Kas, 2) Neraca } \\
\text { dan 3) Laporan laba } \\
\text { rugi serta teknik } \\
\text { pengelolaan } \\
\text { kelembagaan dan } \\
\text { efisiensi biaya dalam } \\
\text { kelompok }\end{array}$ & $\begin{array}{l}\text { Metode } \\
\text { pelatihan, } \\
\text { bimbingan } \\
\text { dan } \\
\text { konsultasi }\end{array}$ & $\begin{array}{l}\text { Kelompok memiliki adminsitrasi } \\
\text { yang baik dan dapat } \\
\text { dipertanggungjawabkan } \\
\text { dengan mudah kepada setiap } \\
\text { anggota kelompok. }\end{array}$ \\
\hline
\end{tabular}

\section{METODE PELAKSANAAN}

\section{Metode Pendekatan}

Guna membantu menyelesaikan masalah pada kelompok mitra ini ada dua pendekatan yang dilakukan yaitu pelatihan serta bimbingan (pendampingan). Pelatihan dan bimbingan dilakukan dengan meters ceramah, diskusi, praktek lapangan, serta layanan konsultasi. Konsultasi dapat dilakukan melalui tatap muka, telepon ataupun melalui surat elektronik dan caracara lainnya yang mungkin dapat dilakukan. Untuk kesinambungan pembinaan, maka seyogyanya daerah ini dijadikan sebagai 
daerah binaan Universitas Andalas.

dibagi dalam tiga kelompok utama Tahapan Kegiatan sebagaimana yang dapat dilihat pada

Secara umum tahapan kegiatan ini dapat Gambar 1.

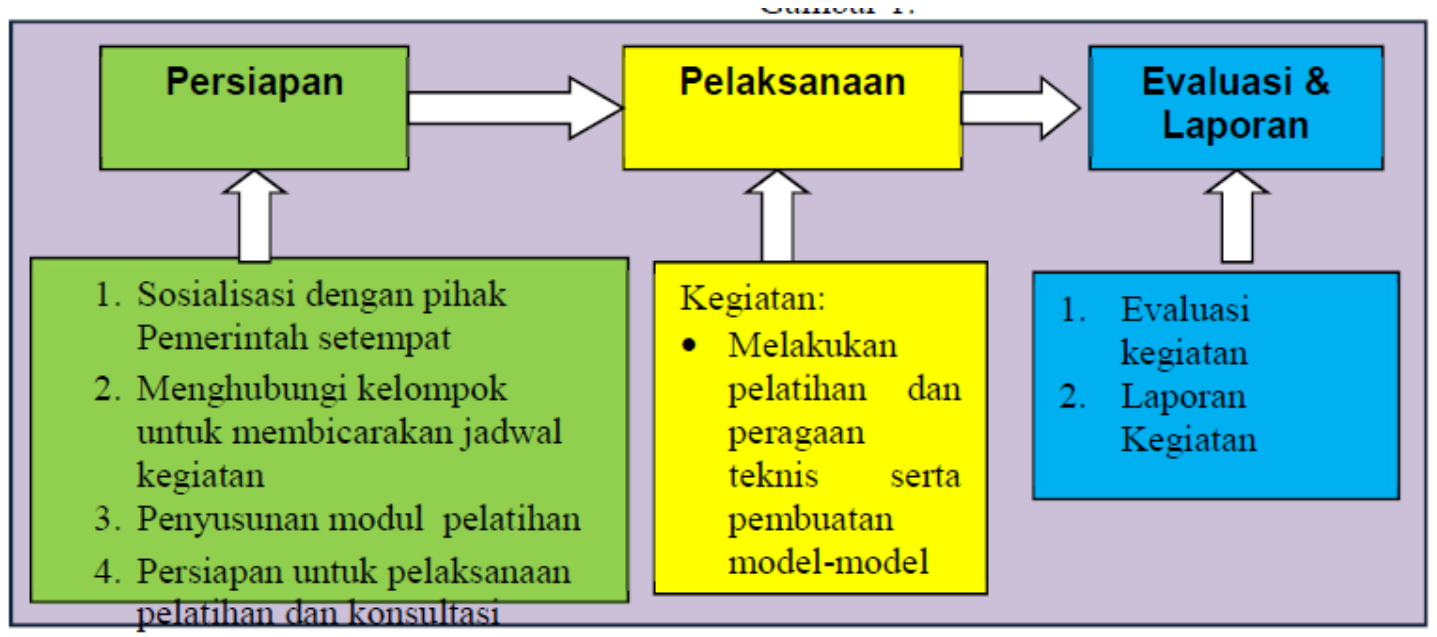

Gambar 1. Tahapan Kegiatan

Pelaksanaan pelatihan dan bimbingan potensi yang ada serta untuk menghasilkan ditujukan untuk mendapatkan kapasitas kualitas kompos yang baik. Lebih rinci dapat kompos yang ideal berdasarkan investasi dan dirumuskan pada Tabel 2 berikut ini:

Tabel 2. Partisipasi Mitra

\begin{tabular}{|l|l|}
\hline Tahap Kegiatan & \multicolumn{1}{|c|}{ Partisipasi } \\
\hline Persiapan & $\begin{array}{l}\text { Kesepakatan kelompok dalam menetapkan anggota yang akan dilibatkan } \\
\text { dalam kegiatan }\end{array}$ \\
\hline Pelaksanaan & $\begin{array}{l}\text { 1. Mengikuti pelatihan dengan materi yang telah disiapkan tim. } \\
\text { 2. Keaktifan dalam mengemukakan permasalahan yang dihadapi }\end{array}$ \\
& $\begin{array}{l}\text { 3. Mempraktekan materi yang telah diajarkan dalam kegiatan pelatihan. } \\
\text { 4. Menyediakan waktu yang cukup untuk melakukan konsultasi } \\
\text { 5. Menetapkan penempatan model yang akan diperagakan. }\end{array}$ \\
\hline $\begin{array}{l}\text { Evaluasi dan } \\
\text { Laporan }\end{array}$ & $\begin{array}{l}\text { 1. Mengikuti program evaluasi hasil kegiatan } \\
\text { 2. Menyampaikan perkembangan usaha dan permasalahan yang dihadapi }\end{array}$ \\
\hline
\end{tabular}

HASIL DAN LUARAN YANG DICAPAI

Pengabdian masyarakat berlangsung dengan lancar di kelompok peternak dan pengolahan susu Kambing Etawa Ranting Ameh di Kayu Rantingan, Nagari Bukit Batabuh Kecamatan Candung Kabupaten Agam. Pengabdian masyarakat Program Studi Teknologi Hasil Pertanian atas biaya dari LPPM (Lembaga Penelitian dan
Pengabdian Masyarakat) Universitas Andalas, dan kerjasama dengan Dinas Pertanian dan Peternakan Kabupaten Agam dan Kelompok Peternak Kambing Ranting Ameh.

Kegiatan penjajakan lokasi pengabdian dan koordinasi dengan dinas Pertanian dan Peternakan Kabupaten Agam telah dilakukan pada tanggal 27 Oktober dan 3 Nopember 2018. Yang dilakukan yaitu melakukan 
tinjauan kelompok peternak Kambing Etawa pada tanggal 1 - 2 Oktober 2018 beberapa anggota kelompok peternak Kambing Etawa secara acak. Berdasarkan hasil tinjauan di lapangan Kelompok peternak Kambing Etawa Ranting Ameh mempunyai anggota sebanyak 20 orang.

Kegiatan pengabdian di Kelompok Peternak Kambing Etawa Ranting Ameh di Jorong Batabuah Koto Baru, Nagari Bukit Batabuh Kecamatan Candung Kabupaten Agam, telah dilaksanakan meliputi kegiatan sebagai berikut:

1. Pelatihan peningkatan pengetahuan dan teknik kebersihan, sanitasi dan higienis pemerahan dan penanganan susu segar dan susu pasteurisasi, serta teknik pengemasan

2. Pelatihan teknik pengolahan susu menjadi berbagai produk olahan susu seperti Yoghurt, Kefir dan Keju Mozarela.

3. Pelatihan wawasan dan pengetahuan kelompok mengenai pemasaran produk olahan susu kambing

1) Pelatihan kemampuan pengelolaan kelembagaan, menyusun laporan keuangan sederhana yaitu; Penyusunan 1) Buku Kas, 2) Neraca dan 3) Laporan laba rugi serta teknik pengelolaan kelembagaan dan efisiensi biaya dalam kelompok.

Dalam tahapan ini dilakukan tanya jawab antara tim pengabdian dengan peserta pelatihan (kelompok peternak).
Peragaan produk yang dilakukan yaitu diajarkan secara langsung kepada para peserta pelatihan pembuatan Yoghurt, Kefir dan Keju Mozarela. Prosedur dan tahapan pembuatan Yoghurt, Kefir dan Keju Mozarela.

Luaran yang telah dicapai dari Program Ipteks Berbasis Prodi Dan Nagari Binaan (IbPSNB) ini adalah:

1. Memenuhi persyaratan Sanitasi dalam pengolahan produk susu

2. Teknik mengolah susu segar menjadi produk olahan susu menjadi Yoghurt, kefir dan Keju Mozarela yang sehat dan higienis

3. Mencari peluang pasar produk olahan susu.

4. Menerapkan adminsitrasi yang baik dan dapat dipertanggungjawabkan dengan mudah kepada setiap anggota kelompok.

5. Publikasi pada jurnal Pengabdian Logista Fateta Unand dengan Volume 2 nomor 2 Tahun 2018 ISSN : 25796238.

\section{RENCANA TAHAPAN BERIKUTNYA}

Rencana tahapan program Pengabdian Iptek berbasis Berbasis Prodi Dan Nagari Binaan (IbPSNB) Bukit Batabuah kecamatan Candung Kabupaten Agam berikutnya dilakukan dalam bentuk tahapan sebagai berikut:

1. Tahapan pertama : Pelatihan pembuatan 36 produk olahan susu Kambing Etawa meliputi pembuatan Yoghurt, Kefir dan 
Keju Mozarela oleh tim pengabdian Program Ipteks Berbasis Prodi Dan Nagari Binaan (IbPSNB)

2. Tahapan kedua: Pelatihan HACCP untuk keamanan pangan produk olahan susu kambing supaya aman untuk dikonsumsi dan terjamin keamanannya

3. Tahapan ketiga : Penyuluhan dan Bantuan Pengurusan izin usaha dan izin edar produk. Bantuan dan bimbingan mengenai cara pengurusan pengurusan izin usaha dan izin edar produk olahan susu Kambing Etawa yang diproduksi oleh Kelompok peternak Kambing Etawa Ranting Ameh Nagari Bukit batabuah sehingga produk aman untuk diedarkan.

4. Tahapan keempat : Bantuan peralatan produksi Alat-alat yang diberikan kepada salah seorang dari kelompok peternak Kambing Etawa adalah peralatan untuk membuat produk olahan susu seperti wadah untuk pengolahan yang terbuat dari stainles steel, mixer, kompor listrik, termometer, pipet.

5. Tahapan Kelima : Monitoring dan Evaluasi Kegiatan ini bertujuan untuk memantau aktivitas mitra setelah tim pengabdian meninggalkan lokasi kelompok peternak kambing. Monitoring dan evaluasi dilakukan oleh Tim Pengadian masyarakat dengan turun langsung ke lokasi. Kegiatan monitoring dan evaluasi ini dilakukan dengan cara: mengadakan diskusi dengan kelompok peternak, mengenai permasalahan yan $_{\delta}$ dihadapi setelah kegiatan pendampingan, sehingga dicari pemecahan persoalan.

\section{KESIMPULAN DAN SARAN}

\section{Kesimpulan}

Kesimpulan yang bisa diambil dari Program Pengabdian Iptek berbasis Berbasis Prodi Dan Nagari Binaan (IbPSNB) pada Kelompok peternak Kambing Etawa Ranting Ameh Jorong Batabuah Koto Baru Kecamatan Candung Kabupaten Agam yaitu

1. Pengabdian masyarakat telah selesai dilaksanakan pada Pengabdian masyarakat bekerja sama dengan LPPM Universitas Andalas, dan Kelompok peternak Kambing Etawa Ranting Ameh di Jorong Batabuah Koto Baru Kecamatan Candung Kabupaten Agam telah mendapatkan pengetahuan dan keterampilan mengenai teknik pembuatan produk olahan susu Kambing Etawa seperti Yoghurt, Kefir dan Keju Mozarela dengan pengemasan dan pelabelan yang sesuai standar yang diberikan penyuluhan dan peragaan langsung.

2. Luaran yang dicapai lainnya yaitu telah diterimanya tulisan (publikasi) tim pengabdian masyarakat yang berjudul pada jurnal Logista Fateta Unand dengan Volume 2 nomor 2

\section{Saran}

Saran dari tim Pengabdian Iptek berbasis Berbasis Prodi Dan Nagari Binaan (IhPSNB) pada Kelompok peternak 37 sumbing Etawa etawa Ranting Ameh 
Jorong Batabuah Koto Baru Kecamatan kelompok peternak Kambing Etawa sampai Candung Kabupaten Agam, yaitu program benar-benar bisa memproduksi produk yang pengabdian masyarakat sebaiknya dilakukan telah dipraktekan sampai diterima dipasaran berkelanjutan setiap tahunnya sampai dan diproduksi secara masal.

\section{DOKUMENTASI KEGIATAN}

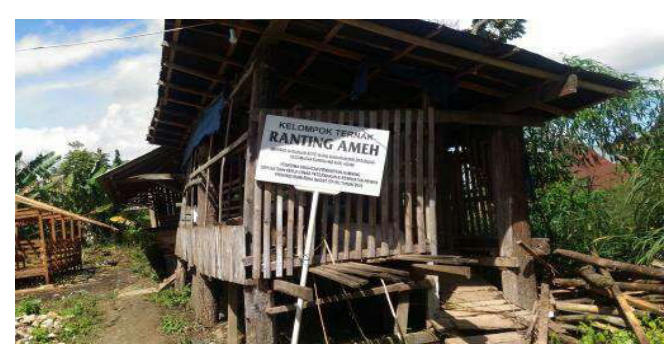

Kandang Kambing Etawa

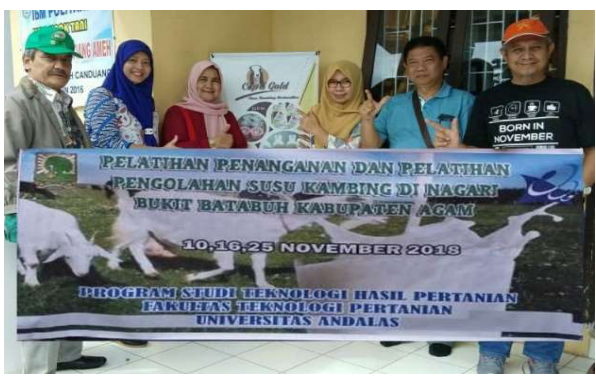

Tim Pengabdian

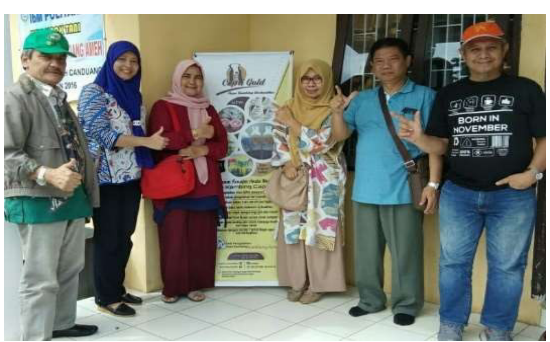

Tim Pengabdian

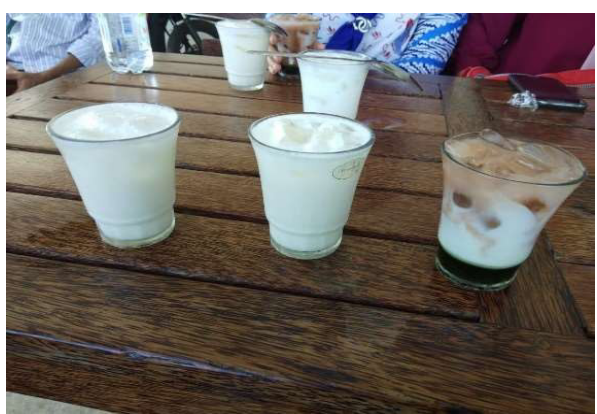

Produk Susu Siap saji

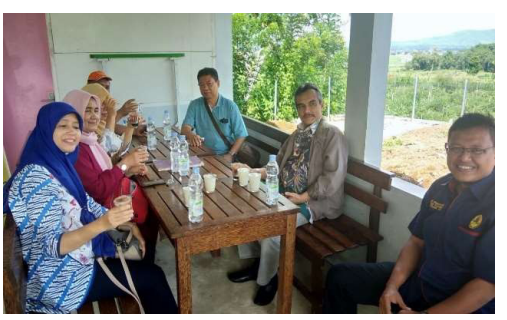

Diskusi dengan Pengelola
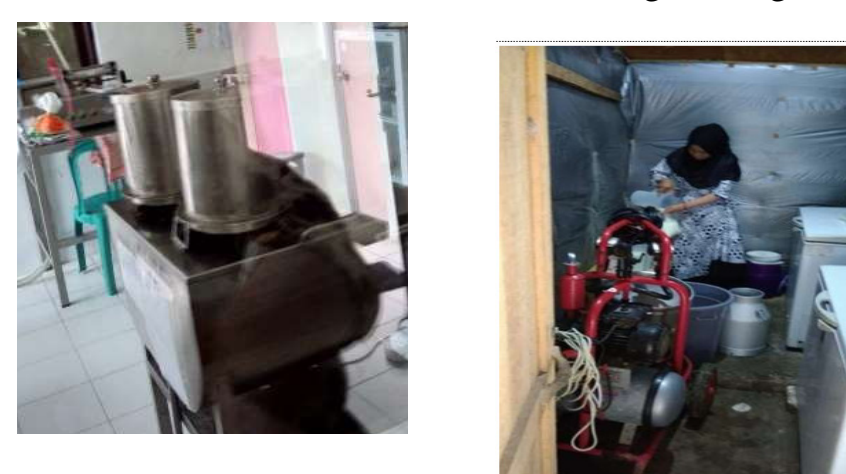

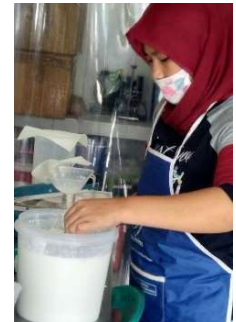

Pembuatan Yoghurt

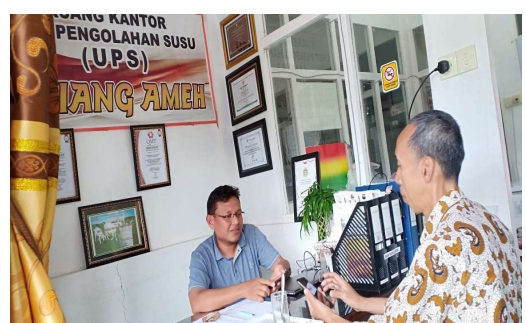


Lembaga Penelitian dan Pengabdian

Universitas Andalas bapak Dr.Ing. Uyung

Gatot Dinata, MT dan Bapak Dekan Fakultas

Teknologi Pertanian Universitas Andalas

atas dukungan moril dan bantuan materi

yang diberikan sehingga terlaksananya

kegiatan Pengabdian ini.

\section{DAFTAR PUSTAKA}

Abubakar., A. Budi, H. Harsono. 1998. Pengaruh susu dan macam susu terhadap mutu yogurt selama penyimpanan. Prosiding Seminar Nasional Peternakan dan Veteriner II : 755 - 760.

Aljokja, S. 2000. Pengaruh Penambahan Pati terhadap Tingkat Keasaman Yoghurt. Thesis. Fakultas Peternakan. Universitas Hasanuddin. Makassar.

Amar, A., H. Brueckner, L. Mertz, G. Migliore. 1997. Manufacturing of camembert cheese like product based on soy protein isolate. Indonesia Biotechnology. Jakarta.

Anonim. 2006a. Keju, Produk Olahan Susu yang Kaya Nutrisi.

Http://www.pikira

n- $\quad$ rakyat.com/cetak/0203/02/1004.htm. Diakses 8 Maret 2006.

Anonim. 2006b. Pengganti rennin dalam Pembuatan

Keju.

Http://ww

w. Bogasarinews. com. Diakses 15 April 2006.

Astuti, T.Y., dan T. Setyawardani. 2006. Penggunaan susu skim dan asam lemak essensial sebagai alternative cara memperbaiki kualitas nutrisi yoghurt. Animal Production, 8(1): $16-21$.

Bari, M.R., R. Ashrafi, M. Alizade, and L. Rofehgarineghad. 2009. Effect of different contents of yogurt starter/ probiotic bacteria, storage time and different concentration of cysteine on the microflora characteristics of Bio-yogurt. Research J. of Biological Science 4(2): $137-142$.

Buckle, K.A. R.A. Edwards, G.N. Fleet and M. Wooton. 1987. Food Science (Ilmu Pangan). Penerjemah Purnomo,
H. dan Adiono. Universitas Indonesia

Press. Jakarta.

Bylund. 1995. Dairy Processing Handbook.

Tetra Pak Processing Systems. Sweden.

Canadian Dairy Commission. 2002. Nilai

Gizi

Yoghurt.

Http://www.canadian.

coms

/yoghurtnilaigizi/com. Diakses 12

Maret 2009.

Davis, J.G. 1991. The microbiology of

yoghourt. Dairy Inds $36: 245-263$.

Goff, H.D., W.B. Combs dan H. Marey. 1993. Milk and Milk Products. Fourth

Editions. McGraw Hill Publishing Company Ltd. Bombay, New Delhi.

Hadiwiyoto, S. 1994. Teori dan Prosedur Pengujian Mutu Susu dan Hasil Olahannya. Lyberty. Yogyakarta.

Herrington, B.L. 1948. Milk and Milk

Processing. Mc.Graw-Hill Book Company, Inc. New York.

Malaka, R. 1999a. Memasyarakatkan Yoghurt dengan Menggunakan Kultur Kering. Lembaga Pengabdian Masyarakat Universitas Hasanuddin. Makassar.

Muchtadi, D dan D. Wardhani. 1996. Mempelajari Penggunaan Jenis rennet dalam Pembuatan Keju Cottage. Bul. Tek. Dan Ind. Pangan. VII (1).

Ressang, A.A. dan A.M. Nasution. 1986. Milk Higiene. Fakultas Kedokteran Hewan. Institut Pertanian Bogor. Bogor.

Soeparno. 1998. Ilmu dan Teknologi Susu. Fakultas Peternakan Universitas Gadjah Mada. Yokyakarta.

Willman, N. 1993. Principles of Cheesemaking. Victorian College of Agriculture and Horticulture. Australia.

Willman N, and C. Willman. 1993. Home Cheese-making. Agromedia East Molbourne. Australia. 